\title{
Renewing Cuchulainn as a National Icon
}

\section{Virginie Girel-Pietka}

\section{(2) OpenEdition}

1 Journals

Electronic version

URL: https://journals.openedition.org/ces/4766

DOI: 10.4000/ces.4766

ISSN: 2534-6695

\section{Publisher}

SEPC (Société d'études des pays du Commonwealth)

\section{Printed version}

Date of publication: 1 September 2016

Number of pages: $79-90$

ISSN: 2270-0633

\section{Electronic reference}

Virginie Girel-Pietka, "Renewing Cuchulainn as a National Icon", Commonwealth Essays and Studies

[Online], 39.1 | 2016, Online since 05 April 2021, connection on 18 June 2021. URL: http:// journals.openedition.org/ces/4766 ; DOl: https://doi.org/10.4000/ces.4766

\section{(c) (i) $(9)$}

Commonwealth Essays and Studies is licensed under a Licence Creative Commons Attribution - Pas d'Utilisation Commerciale - Pas de Modification 4.0 International. 


\section{Renewing Cuchulainn as a National Icon}

The present article shows that Denis Johnston's 1956 pageant of the adventures of $\mathrm{Cu}$ chulainn, the hero of the Irish saga The Tain, was designed to stage humankind's postwar trauma in the middle of a festival dedicated to Irish culture, thus enhancing the cultural bonds between Ireland and the rest of the world and bridging the gap between national culture and international post-World War 2 concerns.

After breaking free from the United Kingdom in 1922, the Irish Free State set about making the new territory coterminous with a nation in its own right. It launched educational and cultural policies inspired from Celtic Revival ideals, namely promoting the Gaelic language and the development of national arts. Yet, this renewed concern for national identity soon took on a protectionist and exclusive dimension that cut Ireland from the rest of the world: the 1923 Censorship of Films Act, the Committee of Enquiry on Evil Literature founded in 1926, and the 1929 Censorship of Publications Act suggest that the State controlled artistic production as much as it supported it, doing its best to protect it from anything deemed immoral or out of tune with a would-be national ethos (Brown 30, 58, 63). In his study of "Ireland and the postcolonial world," Richard Pine therefore points out that the Free State and then the Republic paradoxically adopted "a neo-colonial strategy in order to control the 'canon' of culture" (Pine 24). A postcolonial nation can hardly define itself merely in terms of pre-colonial ancestry or claim some ideal "purity" that would erase the colonizer's legacy and the cultural bonds that remain between colonizers and formerly colonized people. Neither can national identity be defined by the State at the cost of the variety of individuals involved. Pine therefore goes on to argue that such a "neo-colonial strategy" suppressed freedom of speech as it "provide[d] a voice to the new reality when that reality [was] questioned by artists" (Pine 24). He notably refers to the banning of Kate O'Brien's 1941 novel The Land of Spices and of John McGahern's 1965 novel The Dark, after which McGahern left Ireland for a few years. Post-conflict Irish identity may therefore be regarded as a construct promoted by political and religious authorities, a construct that was occasionally challenged by artists endeavouring to reconfigure it.

One of them was Irish playwright Denis Johnston. Born in Dublin in 1901, Johnston grew up in the midst of World War I, the Easter Rising, Ireland's War of Independence and the Irish Civil War - that is to say, in a historical context that continually divided people, at once arousing and challenging their sense of belonging to a nation. His trips abroad, his studies and his early practice as a lawyer made him an acute observer of his time, of society's workings and shortcomings. He also took an interest in theatre and was especially fond of European avant-garde playwrights such as Strindberg, Pirandello and the German expressionists. Back home, he got involved as an actor and a director in the Dublin Drama League, which had been founded by Lennox Robinson and William Butler Yeats in 1918 to present the Dublin audience with foreign, avant-garde dramatic works. While the national drama performed at the Abbey Theatre mostly addressed the question of Irish identity and privileged naturalistic aesthetics, the Dublin Drama Lea- 
gue turned to authors who were experimenting with theatrical form in an attempt to address the individual's loss of bearings in a fast-changing social and political background. When Hilton Edwards and Micheál MacLiammóir founded the Gate Theatre Company in 1928, they followed in the League's footsteps and encouraged young Irish dramatists to try their hands at that new kind of drama. They most notably staged Denis Johnston's first play, The Old Lady Says "No!'” in 1929, after the Abbey, a state-subsidised theatre since 1925, had refused to do so. From the start, Johnston questioned the icons of Irish identity and Free State cultural policies.

In 1947 he gave a radio talk on "the present state of Irish letters" in which he set a new agenda for postwar Irish playwrights. He first remarked that "Irish letters" at the time should refer to writers like Kate O'Brien rather than to W.B. Yeats or Lady Gregory but nonetheless commented more on Irish drama than on anything else. He complained about the "peasant quality" that still prevailed on the Irish stage at a time when a nation should only make sense as part of a worldwide endangered human community. In his view, the cultural particularity advocated by the government of Ireland and by mainstream Irish dramatists in the 1930s and 1940s isolated the nation and prevented it from playing its due part on the worldwide stage. Nationality was no longer seen as a way to gather people but rather denounced as a way to divide them on a larger scale: "Must we then persist in the pursuit of this thing that is to break up civilisation if allowed to go much further?" Johnston entreated his countrymen to "turn their free intelligence - their minds comparatively unsullied by propaganda - from the problems of the noble peasant to the question of human survival" ("Irish letters"1). To him, a writer should help our species by proving an "international man," that is to say, "the man who knows where he comes from and is not ashamed of the fact, but does not allow that knowledge to influence his judgment as to what is best for the human race" ("Irish letters"). His own postwar work should be read in that light: his multifarious experience of history and of art led him to unsettle boundaries and reconfigure national concerns about identity in an international context.

This article focuses on his version of the Irish saga The Táin, "a pageant of the great Cattle Raid of Cooley and of the high deeds of Cuchulainn, Champion of Ulster" (Johnston, The Táin 339). The pageant was a key event in the 1956 An Tostal celebrations, especially as it was presented in Croke Park, the historical home of Gaelic games, of pageants of Celtic mythology in Patrick Pearse's time and of the 1920 Bloody Sunday shooting. An Tostal was an annual festival aiming at celebrating Irish culture. In her study of pageantry in Ireland, Joan Fitzpatrick-Deane explains that

In its early years the Tóstal looked to historical pageantry to attract tourists and to create a version of the Irish past that could involve thousands of citizens in performative supporting roles. In 1954 and 1955, Patrician pageants [of St Patrick] plainly celebrated an independent nation whose defining moment was its conversion to Christianity (Fitzpatrick-Deane 224).

To pick that conversion as "a defining moment" of national identity was another attempt at confining it to a religion. In 1956, the Tóstal festival was also involved in the commemoration of the 1916 Rising, the first Proclamation of the Irish Republic and

1. Rory Johnston granted me leave to use all material relating to his father's non-dramatic works, including unpublished manuscripts. Denis Johnston's collections of manuscripts are kept at the University of Ulster, Coleraine, and at Trinity College, Dublin. 
the bloody repression that followed. The organizers entrusted Hilton Edwards with the task of vetting scripts for a pageant of Cuchulainn, a mythical hero that is associated with the republican Rebels in Irish people's minds. This is how controversial Irish playwright Denis Johnston got an opportunity to bring him back onto the stage. Fitzpatrick-Deane points out that he "freely and syncretically interpolate[d] elements from Arthurian legend, Shakespearean drama, and classical tragedy in his retelling the Irish epic" (Fitzpatrick-Deane 220). I will argue here that Johnston's version of The Táin was designed to stage humankind's postwar trauma in the middle of a festival dedicated to Irish culture, thus enhancing the cultural bonds between Ireland and the rest of the world and bridging the gap between national culture and international post-World War 2 concerns. Johnston dismantles the myth of the noble Irish patriot and warrior only to endow him with renewed meaning and relevance as a myth shedding light on man's predicament. He also made the most of a pageant's theatricality to reach and even involve the audience in a performance that aimed at removing their blinkers.

\section{Reterritorializing the National Hero}

In 1898, Irish revolutionary Patrick Pearse said that "the noble personality of Cuchulainn form[ed] a true type of Gaelic nationality, full as it [was] of youthful life and vigor and hope" (O'Leary 250). As a demigod who pledges allegiance to his host, commits himself to achieving glorious deeds and stands up to invaders until he dies in the line of duty, Cuchulainn was considered a paragon of gallantry and patriotism. In her study of "the Boy as National Hero: the legacy of Cuchulainn," Elaine Sisson shows that Pearse turned him into a role model for young Irish boys joining St Enda's school (Sisson 6). The institution relied on visual and performance arts to spread ideals of masculinity and patriotism among its pupils as well as among the population outside: "Between 1908 and 1912 the boys performed in seven different plays at the Abbey Theatre and numerous others in the school; they also acted in at least six open-air pageants of Irish history at St. Enda's, Jones' Road (now Croke Park) and feiseanna around the country" (Sisson 6). The choice of pageantry emphasizes Pearse's intention to reach the performers as well as their audiences. Fitzpatrick-Deane indeed argues that the "monumental mise en scène" of pageantry aimed at "creat[ing] a dynamic between spectator and spectacle quite unlike that found in conventional drama performed in purpose-built theatres," insofar as, "through such intense, systematic auditory and visual stimulation, pageantry privileges the sensory over the cerebral, the affective over the intellectual" (Fitzpatrick-Deane 5). Pearse's own 1909 pageant The Boy Deeds of Cuchulainn and then his execution in 1916 went on to associate the hero with the revolutionary in Irish people's minds. Cuchulainn also made his way as a national icon thanks to the various writers who popularized his adventures at the time, especially Lady Gregory, who translated Gaelic narratives into English in 1902, and Yeats, who turned them into poems and plays. The hero then became part of de Valera's ${ }^{2}$ rhetoric as well, when the latter had Oliver Sheppard's statue of the dying hero installed in the GPO to commemorate the Rising in 1935. The Proclamation of the Republic and the names of the Rebels who wrote it are engraved on

2. Eamon de Valera (1882-1975) was a major figure of Irish Republicanism in twentieth-century Ireland. From 1917 to 1973 , he served several terms as head of government and as president. A tough opponent of the Partition of Ireland, he played a major part in drafting the 1937 Constitution of Ireland, removing all reference to the king. As President of the Executive Council in the first Fianna Fáil governement from 1932 to 1937, he promoted cultural conservatism. 
a plaque at the foot of the statue so that the hero comes to embody national resistance and to fuel the cult of national martyrdom. Irish Republicanism thus appropriated the famous "Champion of Ulster," paradoxically emphasizing the fact that national culture cannot be confined within the 1922 borders.

Johnston took up the process and carried it further. In the opening scene of his pageant, Fergus, Herald of Ireland, starts introducing the plot in Gaelic, addressing the presidential box in the audience, which lies in the East. He then proceeds to repeat every sentence in English, looking in the opposite direction, thus mapping on the acting area the gap that divides the State from the population. Promoting Gaelic was one of the Free State's priorities but a 1926 poll showed that it only spread among the population through schooling and never became the most popular language in everyday life. In his study of "Ireland's social and cultural history from 1922 to 2002," Terence Brown indeed points out that "no language policy could have had much chance of success which did not tackle the depressed economic conditions of the Irish-speaking districts, and indeed of the slums of Dublin" (Brown 49). Even in the Gaeltachts, the areas in the west of Ireland that were idealized for remaining out of the reach of the colonizers' language and culture, the use of Gaelic had fallen by $41 \%$ (Brown 51). When Fergus first speaks English, he turns his back to the presidential box and significantly addresses the West. Johnston further maps the four Provinces on the field by means of four Trumpeters who punctuate Fergus's introduction in turn and from the four sides. A band finally joins in to play the national anthem. The four Trumpeters conclude it together in unison and the pageant then unfolds in English, as if all the Provinces had opted together for the language inherited from the colonizer. Throughout his career, Johnston complained that conventional Irish drama was confined to realism while, to him, "theatre should be theatrical. It should be a practical expression of the experiences and emotions of the people" (Johnston, "Public Opinion" 89). He therefore added to the saga the theatricality former narratives lacked in an attempt to renew its meaning and drive his message home.

In the "note on the theme" that he included in the programme of his pageant, the dramatist pointed out that no Irish poet had yet done justice to the tale:

it is an amazing fact that no Gaelic Homer or Mallory has ever taken hold of the material and presented it in its entirety in the epic form that it clearly deserves ${ }^{3}$. A few brief summaries can be found in popular books of 'Myth and Legend' and the late Lady Gregory has, of course, recounted most of the main episodes in her Kiltartan prose. But the real text of the Táin itself, whether in Irish or in translation, is almost impossible to come by in any bookshop. And even the Táin contains only the middle part of the story. To find the tremendous denouement one has to go to the libraries and see out the Book of Leinster (Johnston, "The Pageant of Cuchulainn").

One might therefore expect Johnston's pageant to be mostly based on the Book of Leinster. Strangely enough, Johnston's denouement is a far cry from the peaceful ending of that book: "Ailill and Medb made peace with the men of Ulster and with Cuchulainn..." (Unknown 369). In contrast, Johnston's Cuchulainn is led to a most theatrical death. The playwright must have been referring to the "tremendous denouement" of the fight between Cuchulainn and Ferdia, another great warrior in the saga. As the two

3. In 1956, Thomas Kinsella and Ciaran Carson had not yet tried their hands at translating the tale. Lady Gregory's narrative and Yeats's plays were the best-known versions of the story in English. 
warriors were trained together in their boyhood, they are presented as "foster-brothers" (Unknown 227). In Lady Gregory's narrative, as in the tale, dialogues between the two are only developed when they have to fight each other to death because of the Cattle Raid of Cooley, one of the major episodes of the saga. Johnston prefers to stage other aspects of the heroes' lives. In the Book of Leinster, Cuchulainn delivers a heartbreaking lament after he slays his friend, recalling their youth together by their nurse's side:

Then our famous nurse made fast

Our blood-pact of amity,

That our angers should not rise

'Mongst the tribes of noble Elg!

Sad the morn, a day in March,

Which struck down weak Daman's son.

Woe is me, the friend is fall'n

Whom I pledged in red blood's draught! (Unknown 266)

That speech prompted Johnston to create a new scene in which the audience is presented with the development of the heroes' relationship. They meet and take their oath before the cattle raid starts:

FERDIA. Let us swear to be friends, Cuchulainn - now and forever.

Cuchulainn. Friends we are. Let's pledge it to the Death. (Johnston, The Táin 356)

Their bond then gets even stronger as they swear to be blood brothers:

FERDIA. Farewell, Cuchulainn.

Cuchulainn. Farewell, Ferdia.

Вотн. Blood brothers. For all time.

FERDIA. Brothers.

Cuchulainn. Brothers. (Johnston, The Táin 357-8)

Their lines duplicate each other and their voices even merge at one point, as if the pledge actually made them twins. The heroes' pledges testify to their shared sense of duty and to their noble dispositions. Cuchulainn, the role model from Ulster, becomes kin with his counterpart from Connacht. Not only do Johnston's heroes shake hands across what has become Ireland's divide, but their willingness to commit themselves widens the scope of their influence and allows them to embody humanist ideals of kinship and of language and commitment as the foundations of human society. Yet the pageant unfolds to challenge such ideals: Cuchulainn takes several oaths that end up causing his downfall.

Originally called Setanta, Cuchulainn acquires his famous name, which means "the hound of Cullin," when he offers to serve as a watchdog to make up for having slain Cullin's hound. He thus evinces his ability to acknowledge his misdeeds and to make amends. In Gregory's narrative, as in the original tale, Cuchulainn's pledge leads the druid to give him his new name and to associate it with future glory:

"And from this out," he said, "your name will be Cuchulainn, the Hound of Culain." "I am better pleased with my own name of Setanta, son of Sualtim," said the boy. "Do not say that," said Cathbad, "for all the men in the whole world will some day have the name of Cuchulainn in their mouths." "If that is so, I am content to keep it," said the boy. And this is how he came by the name Cuchulainn (Gregory 28). 
In Johnston's pageant, Cuchulainn does not mention the druid so that his name seems as spontaneously adopted as his new condition. While Gregory's narrative enhances his appetite for glory and fame, Johnston first presents him as willing to make up for uncontrolled appetite and to act according to his sense of duty. As a follower of Conchubar he also has to fight and protect Ulster from the invasion of enemies. Because he is a demigod, he is not affected by a curse that is on all Ulster men, which paralyzes them every time their enemies are approaching (Gregory 147-8). More than "the hound of Cullin," Cuchulainn is in fact the watchdog of the whole Province. Noble as it is, his sense of duty nonetheless leads him to demote himself from demigod to watchdog and one may question the validity of a commitment that turns out to be debasing. In his essay entitled The Inbuman, Jean-François Lyotard argues that such is the paradox of humankind: a vulnerable creature at birth, man has a propensity to talk and to get together with his kindred which makes him stronger as a member of a community (Lyotard 11). Culture has therefore been seen as man's "second nature." Humanist as it is, this conception of society involves complying with rules that may go against individual freedom and therefore cripple the individuals' original nature (Lyotard 13). The paradox is all the more striking in The Táin as Cuchulainn is not vulnerable at first. He is a demigod who complies with human rules and forgoes his original name to take on one that emphasizes his tameness. One might then question the validity of rules that weaken individuals instead of making them stronger.

\section{Questioning Heroism}

In the "note on the theme," Johnston draws a parallel between the myth of Cuchulainn and Greek myths, notably as regards "the working of the Geasa or prohibitions that correspond (to some extent) with the immutable decrees of the Fates in the Greek myths" (Johnston, "The Pageant of Cuchulainn"). His pageant emphasizes this connection. When Cuchulainn and Ferdia pledge to be friends till they die, The Morrigan interferes. She is an updated version of Gregory's Morrigu, the goddess of war who often takes the shape of a crow. In Johnston's pageant, The Morrigan takes exception to the warriors' oath: "The Morrigan: Death cannot be the end of Friendship, but the end of Friendship may perhaps be death" (Johnston, The Táin 357). Cuchulainn finds it hard to understand her riddle. As a bird-witch she manipulates language to outwit him. After staging the pledge of brotherhood, Johnston can further depart from his sources and elaborate on the heroes' propensity to pledge allegiance. The Morrigan goes on to bribe them: she offers them new gifts and weapons in exchange for taking new oaths. Ferdia has to pledge that he will never refuse to fight on behalf of a woman he loves while Cuchulainn swears he will never refuse anybody's hospitality. The two heroes take their oaths, still unable to make out the hidden meaning of the Morrigan's words: "How can I be conquered now?" Cuchulainn wonders

The Morrigan. No man can be conquered, Cuchulainn, who does not eat his own strength.

Cuchulainn. I am content. No man will ever eat himself. (With another wild laugh, The Morrigan goes dancing and fluttering off. The two Champions shake hands.) (Johnston, The Táin 357) 
Just as Shakespeare's Macbeth cannot imagine the forest marching on him, Cuchulainn cannot think of any way to eat himself. His readiness to take an oath whenever he is asked to ends up turning one of his pledges against another. His typically human qualities - language and commitment - prove to be tragic flaws.

Cuchulainn and Ferdia's duties to their respective provinces turn out to thwart their pledge of brotherhood. Cuchulainn stands as a gatekeeper at the Ford when Maeve, Queen of Connacht, launches the Cattle Raid of Cooley. She wants to rob Ulster of its most impressive bull at all costs:

MAev. Then run to Dara now, and buy this bull for me.

Mac Roth. He may not sell it, Madam.

MAev. Then borrow it. And if he will not lend, Take it by force. If you lack the power Then send for me and I will bring all Ireland In my train. This bull I mean to have. (Johnston, The Táin 363-4)

Maeve is ready to send her whole people to the slaughter in order to get what she wants and to feel powerful. Staging such a legend in the aftermath of World War II makes it a parable denouncing totalitarian regimes and the way their leaders may abuse their position and waste their subjects' lives. In Gregory's narrative, Maeve is told by her prophetess that she sees "crimson" on her army as the men of Ulster, and especially their glorious hound, will turn the battle into a terrible bloodbath and Maeve's people will blame her for tremendous human loss. The Queen thinks that all the men of Ulster are paralyzed by the curse that is on them so she comforts Fedelma and goes off to conquer the bull, just as she does in the epic tale (Unknown 15-8). In Johnston's pageant, on the contrary, the Queen turns Fedelma's prophecy against her: "Let her see what crimson is," she says, ordering her servant to kill the prophetess. She will not tolerate anyone standing in her way. What the Queen covets thus becomes a burden threatening the population. A picture of the performance shows that the bull was presented as a huge beast whose weight was crushing the people expected to carry it one way or the other:

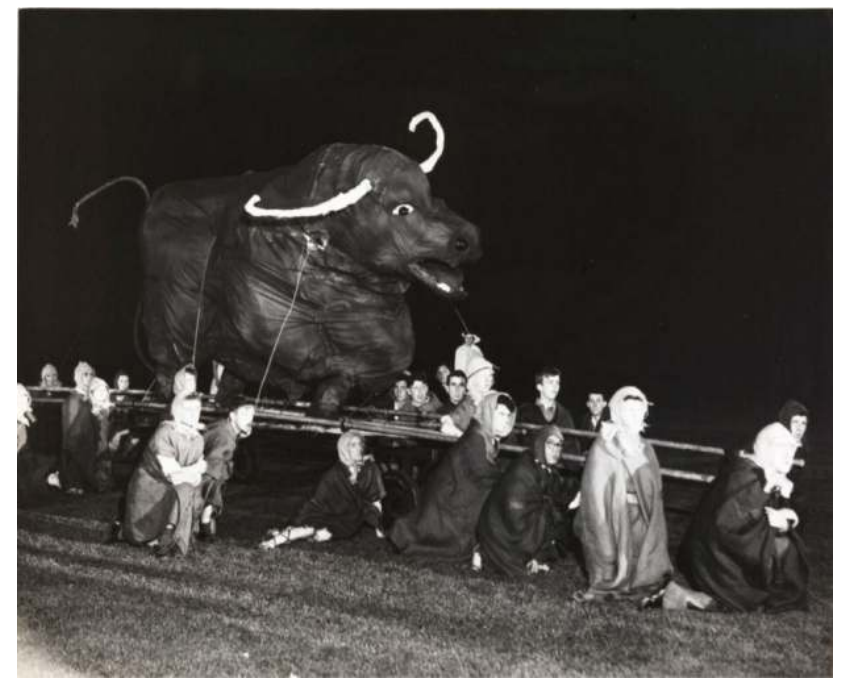

Pageant in Croke Park a numerous cast of walkons pushed and pulled it depending on the progress of Maeve's army or of Cuchulainn; we can see the crowd stumbling under it.

The bull stands out as a kind of golden calf that requires human sacrifices. It becomes a visual metaphor of duty crushing individual freedom and, as such, the scene anticipates Cuchulainn's fate as a defender of his own King and Province. 
Cuchulainn has to kill many a warrior sent by Maeve to conquer the bull of Ulster, including Ferdia. The latter is in love with Maeve's daughter Finnavaur and therefore has to challenge his blood brother on her behalf. Cuchulainn is bound to fight him to death, thus symbolically drawing his own blood. The warrior's duty to his Province proves stronger than his personal bond with Ferdia:

FERDIA (fighting with his feelings). Cuchulainn, they have put a Geis upon me, And I must cross.

Yet we are Brothers, and must not fight.

Cuchulainn. No stranger to Ulster shall cross this Ford in arms

Be he my brother or be he not.

$[\ldots]$

FERDIA. Cuchulainn, I swear I have no wish to break our Bond.

Why then must you oppose me?

Cuchulainn. Stay where you are, Ferdia, and my sword shall do the same.

But cross the Ford, and you are challenging Ulster.

And Ulster is Cuchulainn. (Johnston, The Táin 384-5)

This last statement "Ulster is Cuchulainn," testifies to the fact that the Province identifies with the hero while he doesn't necessarily identify with it - he doesn't say "I am Ulster," as if he talked about himself from a critical distance, observing Ulster and himself, and the collective identity he has come to embody at the cost of any individual personality. Ferdia duplicates Cuchulainn's dehumanizing experience: he too has to break his pledge of brotherhood unwillingly. Not only does he have to serve the woman he loves, Finnavaur, but the latter being Maeve's daughter, she blames him for taking a pledge at the cost of Connacht, his own birthplace. Both warriors are in a dilemma, torn between their duties to their respective Provinces and the personal bond between them. Neither of them is allowed to bridge the gap between the individual and the collective sides of his identity, which causes the downfalls of the two.

When he kills Ferdia, Cuchulainn is confronted with the fulfilment of The Morrigan's prophecy, reminding us of bardic poetry that was read out aloud as public performance and supposedly endowed with performative power. "The end of friendship," that is to say failing to keep one's promise, causes death:

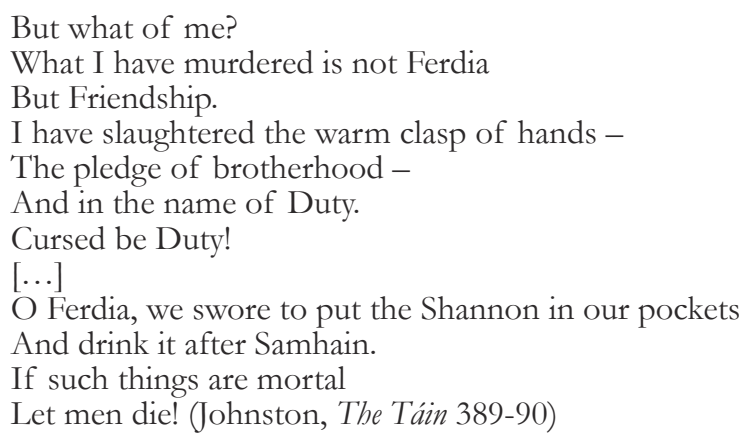

Killing Ferdia means killing friendship itself, and disowning the history that made them kin. He is therefore led to curse humankind for the dehumanizing dimension of its emasculating duties and borders which prevent men from respecting their brothers and from keeping their own words. Those lines may first echo Cuchulainn's lament in the tale: 
All was play, all was sport,

Till came Ferdiad to the ford!

One our life, one our fear,

One our skill in arms.

Shields gave Scathach twain

To Ferdiad and me!

Three things countless on the Táin

Which have fallen by my hand:

Hosts of cattle, men and steeds,

I have slaughtered on all sides! (Unknown 267)

The hero recalls his friendship with Ferdia and seems to repent for his propensity to slaughter people and animals alike. Yet he soon remembers the great fame he derives from all his slaying:

Though the hosts were e'er so great,

That came out of Cruachan wild,

More than third and less than half,

Slew I in my direful sport!

Never trod in battle's ring;

Banba nursed not on her breast;

Never sprang from sea or land,

King's son that had larger fame! (Unknown 267)

In contrast, Johnston's Cuchulainn is denied such soothing thoughts. He goes on to betray more of his kin as he has to accept the hospitality of three crones who have cooked a dog stew and have him eat before he even knows what that is. The Morrigan then appears triumphantly to let him know that he is no longer invincible:

Dog, hound of Cullin, Dog!

You have eaten yourself.

Haha! Haha!

Where are your sinews now? (Johnston, The Táin 394)

The noble demigod who submitted to men's laws and binding language, and who was consequently demoted to the condition of a housedog, is finally turned into a cannibal who indeed eats his own strength by eating his fellow creatures. The dramatist must have had in mind Yeats's play On Baile's Strand, in which Cuchulainn kills a young man on Conchubar's order, unaware that the victim is his own son. When he finds out who he was, he goes out of his mind, runs to the sea and fights the waves as if they were Conchubar himself, symbolically disowning his duty. Johnston rewrites both Gregory's narrative, in which Cuchulainn is the one who tries to talk Ferdia into avoiding the fight, the Book of Leinster, in which Cuchulainn is proud of his "great deeds," and Yeats's play: his Cuchulainn is well aware of his kinship with Ferdia and yet denies it on behalf of his duty to Ulster. Such a predicament exemplifies Jean-François Lyotard's outlook on society's paradoxically dehumanizing dimension. This paradox allows him to challenge the conventional meaning of the "inhuman" accordingly: while it usually refers to behaviour that does not fit in with humanist ideals, the notion may, on the contrary, point to an ability to stand up to society's rules and to resist dehumanization. One might therefore argue that Johnston's pageant somewhat redeems the fallen hero after the legend of his noble disposition has been debunked. 


\section{Reconfiguring Heroism}

As Johnston's Cuchulainn keeps binding himself, he stands for a human being endeavouring to shape his identity. Although he fails to be the brother he wishes to be, he moves on to a final successful attempt to prove a hero and to make his words meaningful again. Having cursed human kind, he proceeds to kill himself. He chooses and stages his own death by tying himself up to a pillar stone in order to make sure that he will die standing rather than bending his knee. Such was already his fate in Gregory's narrative and in Yeats's play The Death of Cuchulainn. In her discussion of Yeats's Cuchulainn plays, Alexandra Poulain argues that the hero actually offers "a profane version of the Passion of Christ." She highlights the theatricality of the cross which exhibits the martyr's body and draws attention to the violence of a State passing such a sentence. She argues that, in The Death of Cuchulainn, the impact of the hero's self-inflicted theatrical death is diminished since the performance is only offered to a blind man. What is more, Poulain goes on, "from the heights of heroic tragedy, the denouement of the play comes crashing down in grotesque triviality, as Cuchulainn is treated as no more than a piece of meat" (Poulain n.p.): the blind man dismembers him with his carving-knife and carries away his glorious head in a bag usually used to beg for leftovers at kitchen doors. $\mathrm{He}$ intends to get a twelve-penny reward for it (Yeats 702). In contrast, Johnston makes the most of the pillar stone as a theatrical device. Unwilling to surrender to Maeve or to bend under the weight of her power, his Cuchulainn escapes his predicament through a final theatrical display of resistance to the enemy. Doing his best to shape his own fate and overcome Maeve's army's destructive drive, he becomes "inhuman" in the redeeming sense envisioned by Lyotard. The other warriors' ferocity to their kindred is thus enhanced:
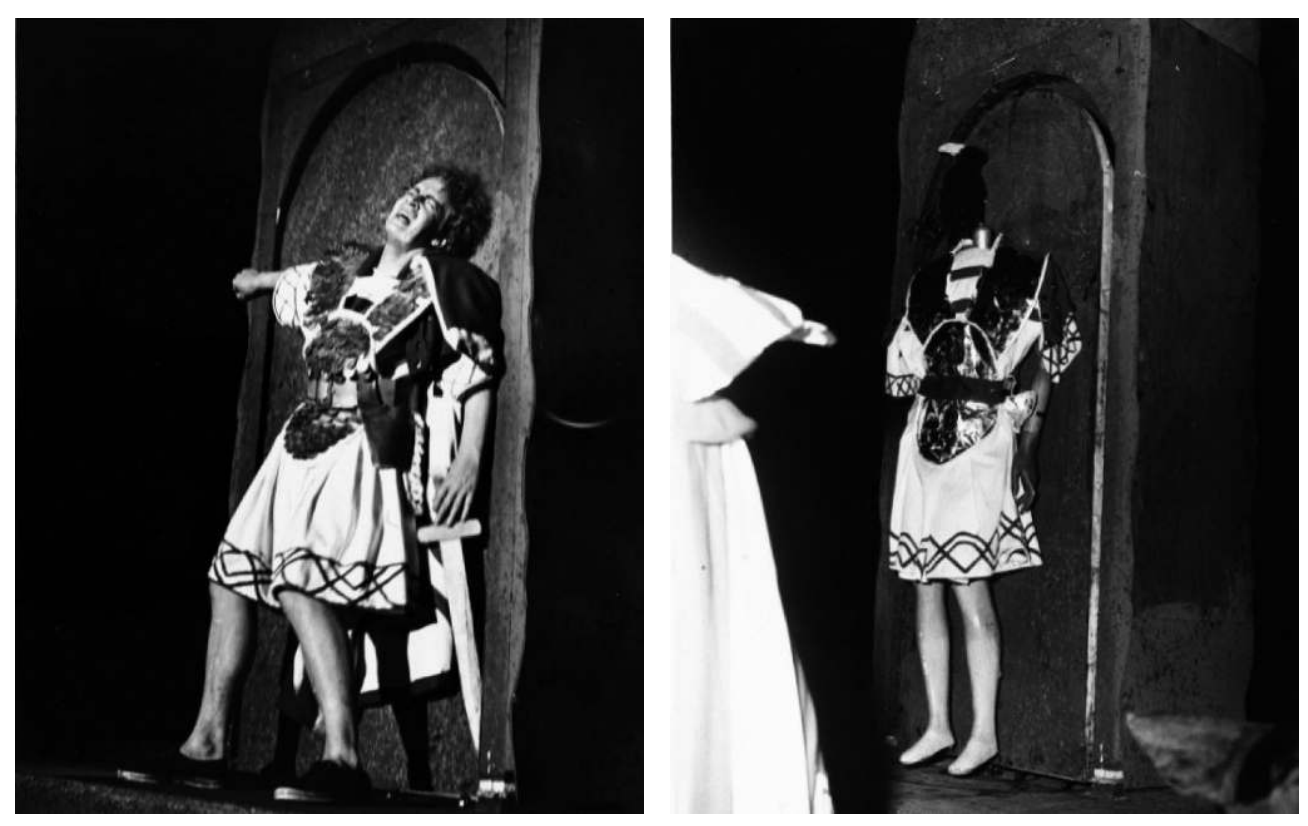

Pageant in Croke Park 
In those pictures of the performance, we can see the actor's face distorted under the blows of Maeve's army and the onslaught of The Morrigan's crows. The crows were enacted by dancers and as they surrounded the dying Cuchulainn, the actor was replaced by a wooden model that made his dismemberment all the more theatrical: we can no longer see any shadow behind that body which turns to dead wood as it is divested of his glorious hand and head. The hero's body becomes a dismembered mannequin drawing attention to Maeve's dehumanizing power. In her study of pageantry, Fitzpatrick-Deane shows that "historical pageants construct narratives that relate, impart, and perpetuate an interpretation of the past shaped less by empirical research or professional historians than by the appropriation of key events and figures to suit the immediate purposes of a community" (Fitzpatrick-Deane 1). Johnston appropriates the Celtic myth and rewrites it to stage a postwar world concerned about "human survival."

The end of the performance further endows Cuchulainn's death with a renewed humanist dimension. Lu, the hero's godly father, comes to pick up his son's hand and head and Conchubar shakes the breath of the severed head into a golden casket that Lu seals and raises proudly above his head, as if sparing the hero's spirit for posterity. He then calls to Ireland to pay a final tribute:

Ireland is one in honouring her warriors.

From north and south and east and west

Come, Gaels and gather at this pyre

Where burns the meanest part of Lu's beloved.

Bring torches, Irishmen,

And carry to your homes

This flaming dust that never shall be quenched. (Johnston, The Táin 399)

After Ireland has paradoxically been united in causing her hero's death, either by fighting him or by binding him to fight, Lu calls for a renewed relation to the hero: the people who light their torches to the pyre and carry home some of the hero's sense of duty and honour, will have to remember that heroism now lies in standing up to potentially dehumanizing collective ideals. Hundreds of walk-ons emerge from all sides of the stadium to light the torches, changing the place into a sea of light and then walking out with it. The walk-ons blur the boundaries between the main performers and the audience. The hero's renewed heroism thus reaches out to the audience. Imagining the Tostal pageant as a large-scale sensory experience allowed Johnston to make the audience aware of the relations between the Cattle Raid of Cooley and the rise of totalitarian regimes. Lu addresses "Gaels" in English rather than in Gaelic so that his message might reach every part of Ireland as well as the rest of the world. Cuchulainn's fate also draws attention to the necessity of standing up to so-called "national" discourses that threaten rather than protect the life of human beings.

Johnston wrote in a notebook that his version of The Táin "played well but was dismissed as a fabrication" (1956 notebook). His pageant stands out as a fabrication indeed, drawing at once on several texts, on the national taste for pageantry and theatricality, and on a worldwide historical context that threatens human kind. The large cast of performers, dancers and musicians as well as actors, and the hundreds of walk-ons involved in the performance, renewed the way the audience was to relate to the show in the midst of the realistic drama that prevailed in 1940s and 1950s Ireland. The dramatist thus staged the way a national icon can be fabricated, challenged, dismembered 
and reinvented. While rewriting the myth into a postwar world that could learn from it as well as Irish patriots may have in their time, Johnston paid tribute to his own cultural legacy which he opened up to contemporary concerns about human survival. In the "note on the theme," he explains that Celtic mythology is "surprisingly human and up-to-date" and turns out to be an "essentially Irish contribution to the heritage of mankind" ("The Pageant of Cuchulainn"). His pageant of Cuchulainn suggests that, although unashamedly Irish, he was an "international man," a writer concerned about the betterment of humankind rather than a watchdog serving only outdated Irish cultural interests.

\author{
Virginie GIREL-PIETKA \\ University of Lille SHS
}

\title{
Works Cited
}

Brown, Terence. A Social and Cultural History of Ireland. 1981. London: Harper Perennial, 2004.

Carson, Ciaran. The Táin, London: Penguin Classics, 2007.

FitzPatrick-Deane, Joan. All Dressed Up, Modern Irish Historical Pageantry. Syracuse, NY: Syracuse UP, 2014.

Gregory, Augusta. Cuchulainn of Muirthemme. 1902. Gerrards Cross: Colin Smythe, 1976.

Johnston, Denis. The Old Lady Says “No!” (1929). Selected Plays by Denis Johnston. Irish Drama Selections 2. Gerrards Cross: Colin Smythe Ltd; Washington, D.C.: The Catholic U of America P, 1983.

—. Tain Bo Cuailgne (1956). Dramatic Works. Vol. 2. Gerrards Cross: Colin Smythe Ltd, 1979.

—. "Public Opinion: A National Morality Play." The Bell. Dublin: March 1941. First published as "A National Morality Play" under Johnston's penname E. W. Tocher in Motley (March 1932).

—. TCD/MS/10066/51/95: notes on The Táin.

—. TCD/MS/10066/78: Denis Johnston's notebook for 1956.

—. TCD/MS/10066/301/118: The Pageant of Cuchulainn - Programme, including "A Note on the Theme" by Denis Johnston.

—. TCD/MS/299/970-1002: pictures of Johnston's pageant in Croke Park, 1956.

—. UUC/MS/B.2iib: "The Present State of Irish letters," 1947.

Kinsella, Thomas. The Táin. Dublin: The Dolmen P, 1969.

LYOTARD, Jean-François. The Inbuman. Stanford, CA: Stanford UP, 1991.

McGahern, John. The Dark (1965). London: Faber \& Faber, 2008.

Poulain, Alexandra. "The Inhuman Body as War-Machine: Yeats's Cuchulainn Plays." Unpublished paper presented at conference "Yeats Revisited," organized by Bertrand Cardin (ERIBA-GREI, EA 2610), University of Caen. 7 January 2012.

O'Brien, Kate. The Land of Spices (1940). London: Virago, 2006.

O'Leary, Philip. The Prose Literature of the Gaelic Revival, 1881-1921, Ideology and Innovation. PennState UP, 1994.

PINE, Richard. The Disappointed Bridge: Ireland and the Postcolonial World. Newcastle-upon-Tyne: Cambridge Scholars Publishing, 2014.

SIsson, Elaine. "The Boy as National Hero: the Legacy of Cuchulainn." UCD Scholarcast 2. Ed. P. J. Matthews. 5 July $2014<$ http://www.ucd.ie/scholarcast/scholarcast2.html>.

The Ancient Irish Epic Tale Táin Bó Cúalnge. Trans. from the Irish (The Book of Leinster) by J. Dunn. 12 September 2014 <http://www.gutenberg.org/files/16464/16464-h/16464-h.htm>.

Yeats, W.B. On Baile's Strand (1904), The Green Helmet (1910), At the Hawk's Well (1916), The Only Jealousy of Emer (1919), The Death of Cuchulainn (1939). The Collected Plays of W.B. Yeats. 1982. Dublin: Gill \& Macmillan, 1989. 